\title{
Penerapan Model Pembelajaran Kooperatif Tipe STAD (Student Teams Achievement Divisions) untuk Meningkatkan Prestasi Belajar Menulis Bahasa Inggris
}

\author{
I Wayan Oka Swabudanta \\ Smk Negeri 1 Tegallalang \\ e-mail: swabudantaoka45@gmail.com
}

\begin{abstract}
Abstrak
Dalam belajar bahasa, ada empat ketrampilan yang perlu dikembangkan yaitu menyimak (listening), berbicara (speaking), membaca (reading), dan menulis (writing). Dari keempat ketrampilan dia atas siswa masih kesulitan terutama pada ketrampilan menulis. Hal ini disebabkan karena beberapa hal, diantaranya : minimnya penguasaan grammar, minimnya penguasaan kosakata (vocabulary mastery), dan ketergantungan siswa kepada guru.Sehingga perlu diadakan inovasi pembelajaran untuk meningkatkan respon dan prestasi belajar siswa. Penelitian ini bertujuan untuk mengetahui peningkatan respon siswa dan peningkatan prestasi belajar Bahasa Inggris siswa kelas XI.AP 1 SMK Negeri 1 Tegallalang melalui penerapan model pembelajaran kooperatif tipe STAD. Dalam penelitian ini menggunakan tahapan siklus dan tiap siklus terdiri dari empat ahap yaitu perencanaan, pelaksanaan rindakan, observasi dan evaluasi, serta refleksi. Subjek yang digunakan dalam penelitian ini adalah siswa kelas XI.AP 1 SMK Negeri 1 Tegallalang tahun pelajaran 2016/2017 sebanyak 38 orang. Dalam pengumpulan data metode yang digunakan adalah metode observasi dan tes hasil belajar. Setelah data yang diharapkan terkumpul semuanya maka dianalisis dengan menggunakan analisis deskriptif. Hasil penelitian ini menunjukkan bahwa dengan menggunakan model pembelajaran kooperatif tipe STAD dapat meningkatkan respon dan prestasi belajar Bahasa Inggris siswa kelas XI.AP 1 SMK Negeri 1 Tegallalang tahun pelajaran 2016/2017.
\end{abstract}

Kata Kunci: Prestasi belajar, kooperatif tipe STAD

\begin{abstract}
In learning languages, there are four skills that need to be developed, namely listening, speaking, reading, and writing. Of the four skills he has for students, there are still difficulties, especially in writing skills. This is due to several things, including: lack of mastery of grammar, lack of mastery of vocabulary, and student dependence on teachers. So there needs to be learning innovations to improve student response and learning achievement. This study aims to determine the increase in student responses and improvement in learning achievement of English students of class XI.AP 1 of State Vocational High School 1 Tegallalang through the application of the STAD type cooperative learning model. In this study using cycle stages and each cycle consists of four stages, namely planning, action, observation and evaluation, and reflection. The subjects used in this study were class XI.AP 1 students of SMK Negeri 1 Tegallalang 2016/2017 academic year as many as 38 people. In data collection the method used is the method of observation and test results. After all the data that is expected to be collected, then it is analyzed using descriptive analysis. The results of this study indicate that using the STAD type cooperative learning model can improve the response and learning achievement of English students of class XI.AP 1 in SMK Negeri 1 Tegallalang 2016/2017 academic year.
\end{abstract}

Keywords: Learning achievement, cooperative type STAD 


\section{Pendahuluan}

Undang - Undang nomor 20 tahun 2003 tentang Sistem Pendidikan Nasional pasal 1 butir 19 yang menjelaskan bahwa kurikulum adalah seperangkat rencana dan pengaturan mengenai tujuan, isi, dan bahan pelajaran serta cara yang digunakan sebagai pedoman penyelenggaraan kegiatan pembelajaran untuk mencapai tujuan tertentu.

Era globalisasi membawa dampak semakin pesatnya kemajuan ilmu pengetahuan dan teknologi. Hal ini membawa konsekuensi bagi banyak aspek terutama pendidikan baik formal maupun non-formal. Pendidikan formal dihadapkan pada kurikulum yang selalu berubah sesuai dengan perkembangan pendidikan kekinian. Setiap perubahan yang terjadi tidak lain ditujukan untuk memperbaiki dan melakukan perubahan menuju arah yang lebih baik. Sebagaimana yang diungkapkan oleh Kemdikbud, (2013:83) bahwa kurikulum dikembangkan untuk membangun kehidupan masa kini dan masa yang akan datang bangsa, yang akan dikembangkan dari warisan nilai dan prestasi bangsa di masa lalu, serta kemudian diwariskan serta dikembangkan untuk kehidupan masa depan.

Bahasa Inggris merupakan alat untuk berkomunikasi secara lisan dan tulisan. Berkomunikasi adalah memahami dan mengungkapkan informasi, pikiran, perasaan, dan mengembangkan ilmu pengetahuan, teknologi dan budaya. Pembelajaran Bahasa Inggris dapat membantu peserta didik mengemukakan gagasan dan perasaan, berpartisipasi dalam masyarakat dan bahkan menemukan serta menggunakan kemampuan analitis dan imajinatif yang ada dalam dirinya.

Dalam belajar bahasa, ada empat ketrampilan yang perlu dikembangkan. Ketrampilanketrampilan tersebut meliputi ketrampilan menyimak (listening), ketrampilan berbicara (speaking), ketrampilan membaca (reading), dan ketrampilan menulis (writing). Agar menguasai ketrampilan tersebut diatas siswa perlu dibekali dengan unsur-unsur bahasa misalnya kosakata, penguasaan tata bahasa, ucapan, dan intonasi. Penguasaan keempat hal di atas mempermudah siswa untuk memahami dan merespon makna baik secara lisan maupun tulis dalam teks fungsional, transaksional, dan monolog yang berbentuk report, descriptive, recount, narrative, dan procedure. Namun pada kenyataannya meskipun sudah berbekal kosakata, pengetahuan tentang tata bahasa, intonasi, dan ucapan masih ditemukan banyak kesulitan untuk memahami teks, terutama teks monolog yang cenderung lebih panjang daripada teks fungsional. Dari keempat ketrampilan yang harus dikuasai oleh siswa ketrampilan menulis cenderung lebih sulit. Permasalahan ini juga merupakan masalah bagi siswa - siswi di SMK Negeri 1 Tegallalang terutama di kelas XI AP 1. Rendahnya prestasi belajar siswa di kelas tersebut tercermin dari nilai ulangan harian siswa kelasXI AP 1 semester I tahun pelajaran 2016/ 2017 dari daftar nilai rata - rata kelas hanya 58,00. Hal ini juga memperlihatkan masih rendahnya hasil belajar Bahasa Inggris siswa di kelas tersebut terutama dalam memahami dan menyusun teks monolog. Rendahnya prestasi belajar terlihat dari ulangan harian pada poin menyusun kalimat pada teks monolog. Siswa masih kesulitan terutama pada ketrampilan menulis. Hal ini disebabkan karena beberapa hal, antara lain : (1) Minimnya penguasaan grammar pada siswa mengingat bahasa Inggris adalah bahasa asing di Indonesia sehingga siswa tidak menggunakan tata bahasanya pada kehidupan sehari - hari. Meskipun pendekatan Bahasa Inggris SMK adalah genre based learning namun pemahaman tentang grammar sangat diperlukan dalam penyusunan teks. Terutama Present dan Past tense. (2) Minimnya penguasaan kosakata (vocabulary mastery) pada siswa, mengingat bahasa Inggris adalah bahasa asing di Indonesia. (3) Motivasi belajar siswa rendah sehingga siswa kurang aktif dalam mengikuti pembelajaran. Hal ini bisa dilihat dari kebanyakan siswa yang malas membuka kamus ketika menemukan kalimat/kata yang sukar atau baru mereka temui pertama kali. Mereka lebih suka langsung bertanya pada gurunya, dengan kata lain mereka tidak terbiasa menemukannya sendiri. Siswa hanya menerima apa yang diberikan oleh guru, sehingga pengetahuan yang dimiliki siswa hanya sebatas pada apa yang diberikan olah gurunya, pengetahuan ini pun bersifat sementara karena siswa tidak membangun pengetahuannya sendiri. (4) Ketergantungan siswa kepada guru juga dipengaruhi oleh pembelajaran selama ini yang sebagian besar masih melakukan teacher-center learning. Banyak guru yang masih menggunakan metode ceramah untuk mentransfer ilmu kepada siswa, sehingga siswa tidak berkesempatan untuk mempelajari terlebih dahulu materi yang akan dibahas. Menurut Hastut (2017) Faktor yang paling menentukan keberhasilan pendidikan/pengajaran adalah guru, sehingga guru sangat dituntut kemampuannya untuk menyampaikan bahan pengajaran kepada siswa dengan baik, untuk itu guru perlu 
mendapatkan ilmu pengetahuan tentang metode dan media pengajaran yang dapat digunakan dalam proses belajar mengajar.

Berdasarkan permasalahan di atas, guru perlu memberikan respon positif secara konkret dan objektif yang berupa membangkitkan partisipasi siswa, baik dalam bentuk kontributif maupun inisiatif yang semata - mata bertujuan untuk meningkatkan prestasi belajar siswa. Salah satu hal yang perlu dilakukan adalah memperbaharui metode yang digunakan sehingga proses belajar dapat berlangsung kondusif dan menyenangkan.

Model yang bisa diterapkan agar siswa bisa lebih berpartisipasi dalam pembelajaran adalah model pembelajaran kooperatif. Ada beberapa tipe model pembelajaran kooperatif yaitu Student Teams Achievement Divisions (STAD), Teams-Games-Tournament (TGT), Jigsaw, Group Investigation (GI) and Dyadic (Keller, 2006; 86). Model pembelajaran kooperatif yang digunakan pada penelitian ini adalah tipe STAD yang menekankan pada aktivitas dan interaksi diantara siswa untuk saling memotivasi dan saling membantu dalam menguasai materi. Student Teams Achievement Division (STAD) merupakan salah satu strategi pembelajaran kooperatif yang di dalamnya beberapa kelompok kecil siswa dengan level kemampuan akademik yang berbeda-beda saling bekerja sama untuk menyelesaikan tujuan pembelajaran. Tidak hanya secara akademik, siswa juga dikelompokkan secara beragam berdasarkan gender, ras, dan etnis (Rusman, 2012, hal. 201). Menurut Kadang (2017) STAD merupakan variasi pembelajaran kooperatif yang paling banyak diteliti, dan merupakan model yang paling baik untuk memacu siswa agar saling mendorong dan membantu satu sama lain untuk menguasai keterampilan yang diajarkan guru. Slavin dalam (Rusman, 2014:214) menyatakan bahwa: "Gagasan utama di belakang STAD adalah memacu siswa agar saling mendorong dan membantu satu sama lain untuk menguasai keterampilan yang diajarkan oleh guru". Menurut Wardana (2017) Model pembelajaran kooperatif tipe STAD menekankan pada kerja sama kelompok. Dengan dilakukan kerja kelompok diharapkan akan melatih siswa untuk mengungkapkan pendapat dan meningkatkan pemahaman konsep secara bersama, serta dengan terjalinnya kerja sama kelompok dengan baik maka siswa dapat lebih memahami konsep yang ada dengan bantuan temannya. Keunggulan pembelajaran koopertatif tipe STAD terletak pada langkah-langkah pembelajaran yang diterapkan. Penerapan model pembelajaran kooperatif tipe STAD diharapkan mampu meningkatkan hasil belajar siswa. Keunggulan pembelajaran kooperatif tipe STAD yaitu siswa bekerja dalam kelompok sehingga siswa dapat memahami konsep materi yang ada dengan bantuan teman kelompok mereka. Menurut Widyastuti (2012) Keunggulan dari metode pembelajaran kooperatif tipe STAD adalah adanya kerja sama dalam kelompok dan dalam menentukan keberhasilan kelompok tergantung keberhasilan individu, sehingga setiap anggota kelompok tidak bisa menggantungkan pada anggota yang lain dengan menggunakan kuis-kuis individual pada tiap akhir pelajaran. Pembelajaran kooperatif tipe STAD menekankan pada aktivitas dan interaksi diantara siswa untuk saling memotivasi saling membantu dalam menguasai materi pelajaran guna mencapai prestasi yang maksimal.

Berdasarkan paparan di atas, untuk meningkatkan prestasi belajar Bahasa Inggris kelas XI AP 1 SMK Negeri 1 Tegallalang diperlukan suatu perubahan dalam pelaksanaan pembelajaran pada KD, mengungkapkan bahwa makna dan langkah retorika essay pendek, sederhana dengan menggunakan ragam bahasa lisan secara akurat, lancar, dan diterima untuk berinteraksi dengan lingkungan sekitar berbentuk recount dan narrative, yaitu dengan menerapkan pembelajaran kooperatif tipe STAD.

\section{Metode}

Penelitian ini termasuk jenis Penelitian Tindakan Kelas (Classroom Action Research) yang secara umum bertujuan untuk meningkatkan dan memperbaiki proses kegiatan pembelajaran. Penelitian tindakan kelas ini dilaksanakan di SMK Negeri 1 Tegallalang yang berlokasi di Desa Pejeng Aji, Kecamatan Tegallalang, Kabupaten Gianyar, dengan subjek penelitian siswa kelas XI AP1

\section{Prosedur Penelitian}

Penelitian ini merupakan penelitian tindakan kelas untuk memperbaiki kualitas pembelajaran dalam meningkatkan hasil belajar siswa. Dalam prosedur penelitian, maka model penelitian tindakan yang akan digunakan adalah model tindakan yang dikemukakan oleh Arikunto, (2008:16) yang terdiri dari empat tahapan yaitu perencanaan, pelaksanaan, pengamatan dan refleksi. Adapun model dan penjelasan untuk masing-masing tahapan adalah sebagai berikut. 


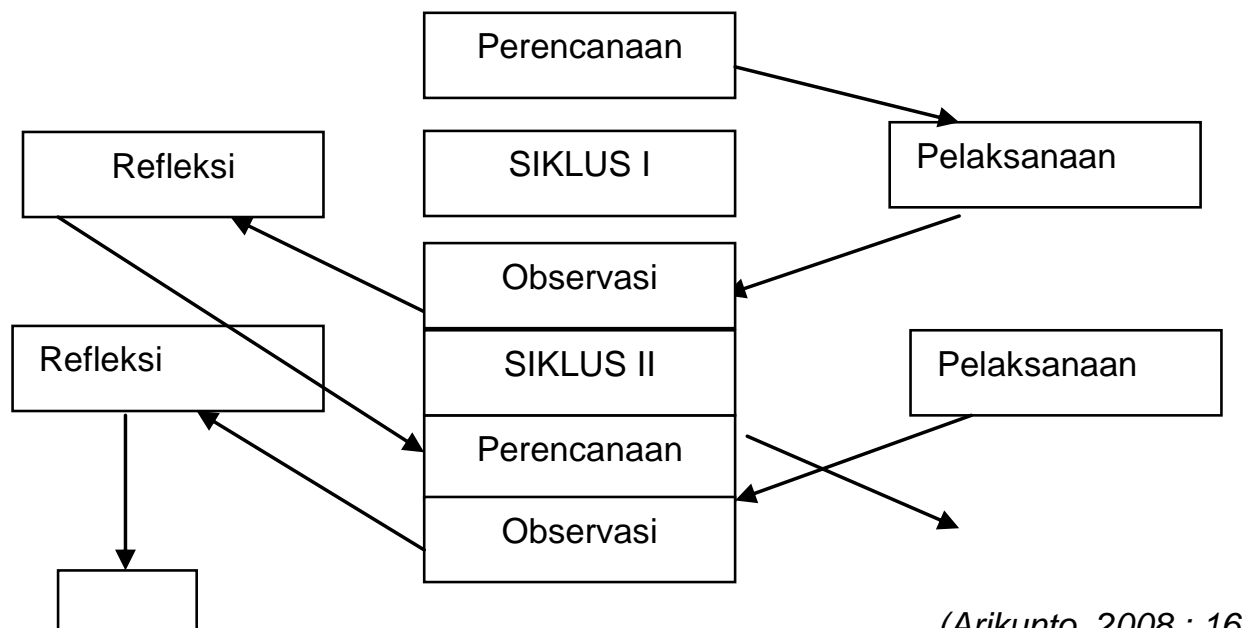

(Arikunto, 2008: 16)

Gambar 1. Siklus Penelitian Tindakan Kelas

Siklus I

Perencanaan Tindakan

Perencanaan ini digunakan untuk menyusun rencana tindakan yang hendak dilakukan dalam pembelajaran Bahasa Inggris. Rencana disusun secara fleksibel guna mengembangkan berbagai kemungkinan yang timbul di kelas yang tidak dapat diduga terlebih dahulu, adapun kegiatan yang dilaksanakan pada tahap ini adalah sebagai berikut: (1). Menyiapkan materi yang dirancang untuk pembelajaran secara berkelompok.(2). Menetapkan siswa dalam kelompok. Membentuk kelompok yang terdiri dari $4-5$ orang dengan kemampuan yang akademik yang heterogen (3). Menyusun Rencana Pelaksanaan Pembelajaran (RPP) dan menyiapkan buku LKS sesuai dengan pendekatan kooperatif tipe STAD. 4). Menyusun instrumen penilaian berupa tes prestasi belajar dan angket siswa.

\section{Pelaksanaan Tindakan}

Pada tahap ini merupakan tahap mempraktekan rencana yang telah disusun dalam proses pembelajaran di kelas. Setiap pembelajaran dalam STAD dimulai dengan presentasi kelas yang meliputi pendahuluan, pengembangan, praktek terkendali yang melibatkan aktivitas kelompok dan kuis.

1. Pendahuluan

Pada kegiatan pendahuluan hal-hal yang perlu dilakukan adalah (a) Mengucapkan salam kepada siswa. (b) Memeriksa absensi / kehadiran siswa. (c) Menjelaskan tujuan yang ingin dicapai pada pembelajaran. (d) Apersepsi /memberikan motivasi kepada siswa dalam pembelajaran. (e) Menjelaskan materi secara garis besar yang akan dipelajari dan mengapa hal itu penting untuk dipelajari. Hal ini bertujuan untuk rasa ingin tahu siswa.

2. Kegiatan Inti

(Pengembangan dan Latihan Terbimbing) yaitu : (a) Meminta siswa untuk membentuk kelompok dan menjelaskan bahwa nantinya mereka harus belajar dan bekerja dalam kelompok. (b) Meminta siswa mengerjakan soal atas pertanyaan yang diberikan pada LKS. (c) Selama belajar kelompok, meminta siswa untuk menguasai materi yang diberikan guru dan membantu teman sekelompoknya untuk menguasai materi tersebut. Mengingatkan siswa jika mereka mempunyai pertanyaan sebaiknya menanyakan pada teman sekelompoknya sebelum menanyakan pada guru. (d) Sesekali melakukan pengawasan kepada siswa dengan cara mendekati kelompok dan mendengarkan bagaimana anggota kelompok berdiskusi. (e) Memanggil siswa secara acak untuk menyelesaikan soal. Dan mempresentasikanya di depan kelas. Hal ini bertujuan supaya semua siswa mempersiapkan diri sebaik mungkin.

3. Penutup

Pada kegiatan penutup kegiatan yang dilakukan adalah (a) Melaksanakan tes prestasi belajar bahasa Inggris siklus I atau II. (b) Penghargaan kelompok 


\section{Observasi dan Evaluasi}

Pada tahap observasi, peneliti mengamati kegiatan siswa selama pembelajaran untuk memperoleh gambaran mengenai kelebihan dan kekurangan yang terjadi dalam proses pembelajaran yang akan digunakan sebagai dasar untuk melakukan perbaikan pada proses pembelajaran berikutnya.

Berdasarkan observasi yang dilakukan, guru melakukan evaluasi secara umum untuk mengetahui seberapa besar keberhasilan tindakan yang dilakukan pada siklus tersebut. Tujuan dari proses ini adalah untuk mengetahui peningkatan hasil belajar siswa, dan memperoleh gambaran tentang kelebihan dan kekurangan dari pelaksanaan pembelajaran.

\section{Refleksi}

Hasil yang didapatkan pada tahap ini dikumpulkan kemudian dianalisis dengan teknik anlisis deskriptif kuantitatif. Dari hasil tersebut dapat digunakan sebagai dasar mengevaluasi kegiatan yang telah dilaksanakan apakah kegiatan yang telah dilaksanakan dapat meningkatkan motivasi dan hasil belajar siswa, dengan mengetahui kekurangan dan kelemahan pada tindakan ini maka dapat dipergunakan sebagai acuan perbaikan pada perencanaan berikutnya.

Siklus II

Pada prinsipnya prosedur dan langkah - langkah yang dilaksanakan pada siklus II sama dengan siklus I. Pembelajaran yang dilakukan oleh guru tatap menggunakanmetode pembelajaran kooperatif tipe STAD. Hanya saja pada siklus II dilakukan penyempurnaan tindakan dari siklus I.

Pada akhir siklus II dilakukan refleksi secara keseluruhan terhadap pelaksanaan pembelajaran. Kegiatan refleksi dilakukan oleh guru berdasarkan hasil observasi dan evaluasi yang dilakukan pada akhir siklus II. Refleksi pada akhir siklus II ini bertujuan untuk mengetahui berhasil tidaknya pemberian tindakan dan mengkaji kendala - kendala atau hambatan yang ditemui pada siklus II.

Metode yang digunakan untuk mengumpulkan data adalah tes dan observasi. tes digunakan untuk mengukur ranah kognitif siswa pada mata pelajaran Bahasa Inggris. Dalam penelitian ini akan dipergunakan alat ukur essay untuk memperoleh data hasil belajar siswa. Skor prestasi belajar masing - masing siswa diperoleh dengan menjumlahkan skor yang diperoleh masing - masing siswa pada setiap butir soal, sehingga skor maksimal 100. Sedangkan observasi digunakan untuk mengumpulkan data tentang perilaku siswa, aktivitas, partisipasi siswa dalam menerima pelajaran.

Setelah data terkumpul semuanya selanjutnya diadakan analisis dengan menggunakan analisis statistik deskriptif. Yang dikasud dengan analisis deskriptif adalah menggambarkan hasil penelitian secara sistematis kemudian ditarik suatu kesimpulan umum baik berupa narasi maupun dalam bentuk grafik.

\section{Hasil dan Pembahasan}

Tindakan siklus I dilaksanakan sebanyak 3 kali pertemuan, 2 kali pertemuan untuk proses pembelajaran dan 1kali pertemuan untuk evaluasi. Semua siswa kelas XI AP 1 hadir baik pada pertemuan I sampai pertemuan II. Pada siklus ini diimplementasikan rencana tindakan yang terdapat pada skenario pembelajaran. Pelaksanaan tindakan siklus I secara rinci diuraikan pada bagian berikut ini.

Berdasarkan identifikasi masalah analisis penyebab timbulnya masalah pada proses pembelajaran sebelum tindakan kelas dilakukan, maka diambil tindakan pemecahan masalah yang dipandang tepat, yaitu dengan menerapkan pembelajaran dengan menggunakaan metode pembelajaran kooperatif tipe STAD.

Langkah yang dilakukan selanjutnya adalah menyusun alat-alat penelitian yang mengacu pada pembelajaran dengan menggunakan metode pembelajaran kooperatif tipe STAD. Materi pembelajaran yang diajarkan pada siklus I adalah penggunaan dan penyusunan kalimat present tense. Pada awal siklus I peneliti mengelompokkan siswa menjadi 8 kelompok yang heterogen. Pembentukan kelompok ini hanya dilakukan pada awal siklus, untuk pembelajaran selanjutnya siswa ditempatkan pada kelompok yang sama. Kegiatan yang dilakukan antara lain adalah guru menyampaikan tentang teknik metode pembelajaran kooperatif tipe STAD yang akan diterapkan dalam proses pembelajaran dan menjelaskan materi. Guru menyiapkan kondisi fisik siswa, yang meliputi mengabsen siswa, menyiapkan buku pelajaran. 
Guru juga menyampaikan tujuan proses dan tujuan efektif siswa serta menginformasikan pembelajaran yang akan dilakukan. Tetapi, situasi kelas pada saat itu belum bisa terkendali karena masih ada sebagian siswa yang ramai sendiri. Untuk itu, guru berusaha menegur dan melanjutkan kembali pelajaran dengan mempresentasikan materi yang akan dipelajari.

Selanjutnya guru memberikan tugas untuk dibahas oleh kelompok. Setelah selesai, guru memberikan kunci jawaban untuk dibahas bersama. Langkah terakhir dari tindakan ini adalah guru memberikan soal evaluasi sebagai tes akhir siklus I.

Setelah pembelajaran selesai, guru menutup pelajaran dengan memberikan motivasi dan menginformasikan pada siswa untuk benar-benar belajar dirumah untuk menyiapkan materi yang akan disampaikan pada pertemuan selanjutnya. Untuk lebih jelasnya hasil Tes sebelum tindakan, siklus I dan siklus II dapat dilihat pada Tabel rekapitulasi berikut ini.

Tabel 1. Rekapitulasi Hasil Tes Sebelum Tindakan, Siklus I dan Siklus II

\begin{tabular}{|c|c|c|c|c|c|c|c|c|c|}
\hline \multirow[t]{2}{*}{ No. } & \multicolumn{3}{|c|}{ Data awal } & \multicolumn{3}{|c|}{ Siklus I } & \multicolumn{3}{|c|}{ Siklus II } \\
\hline & $\begin{array}{l}\text { Nilai } \\
\text { Tes }\end{array}$ & $\begin{array}{l}\text { Freku } \\
\text { ensi }\end{array}$ & $\begin{array}{l}\text { Jumlah } \\
\text { nilai }\end{array}$ & $\begin{array}{l}\text { Nilai } \\
\text { Tes }\end{array}$ & $\begin{array}{l}\text { Freku } \\
\text { ensi }\end{array}$ & $\begin{array}{l}\text { Jumla } \\
\text { h nilai }\end{array}$ & $\begin{array}{l}\text { Nilai } \\
\text { Tes }\end{array}$ & $\begin{array}{l}\text { Freku } \\
\text { ensi }\end{array}$ & $\begin{array}{l}\text { Jumlah } \\
\text { nilai }\end{array}$ \\
\hline 1 & 50 & 1 & 50 & 55 & 4 & 220 & 65 & 1 & 65 \\
\hline 2 & 55 & 6 & 330 & 60 & 2 & 120 & 70 & 11 & 770 \\
\hline 3 & 60 & 2 & 120 & 65 & 6 & 390 & 75 & 10 & 750 \\
\hline 4 & 65 & 11 & 715 & 70 & 5 & 350 & 80 & 7 & 560 \\
\hline 5 & 70 & 10 & 700 & 75 & 10 & 750 & 85 & 4 & 340 \\
\hline 6 & 75 & 5 & 375 & 80 & 8 & 640 & 90 & 5 & 450 \\
\hline 7 & 80 & 3 & 240 & 85 & 3 & 255 & . & & \\
\hline $\mathrm{N}$ & & 38 & & & 38 & & & 38 & \\
\hline \multicolumn{3}{|c|}{ Jumlah } & 2530 & & & 2725 & & & 2935 \\
\hline \multicolumn{3}{|c|}{ Rata-rata } & 66,58 & & & 7171 & & & 77,24 \\
\hline \multirow{2}{*}{\multicolumn{3}{|c|}{$\begin{array}{l}\text { Daya serap } \\
\end{array}$}} & $66,58 \%$ & & & $71,71 \%$ & & & $77,24 \%$ \\
\hline & & & $52,63 \%$ & & & $68,42 \%$ & & & $97,37 \%$ \\
\hline
\end{tabular}

Bila data diatas disajikan dalam bentuk grafik maka prestasi belajar Bahasa Inggris siswa dapat dilihat pada gambar berikut, yang mencerminkan kemajuan hasil belajar dari sebelum tindakan, siklus I sampai dengan siklus II.

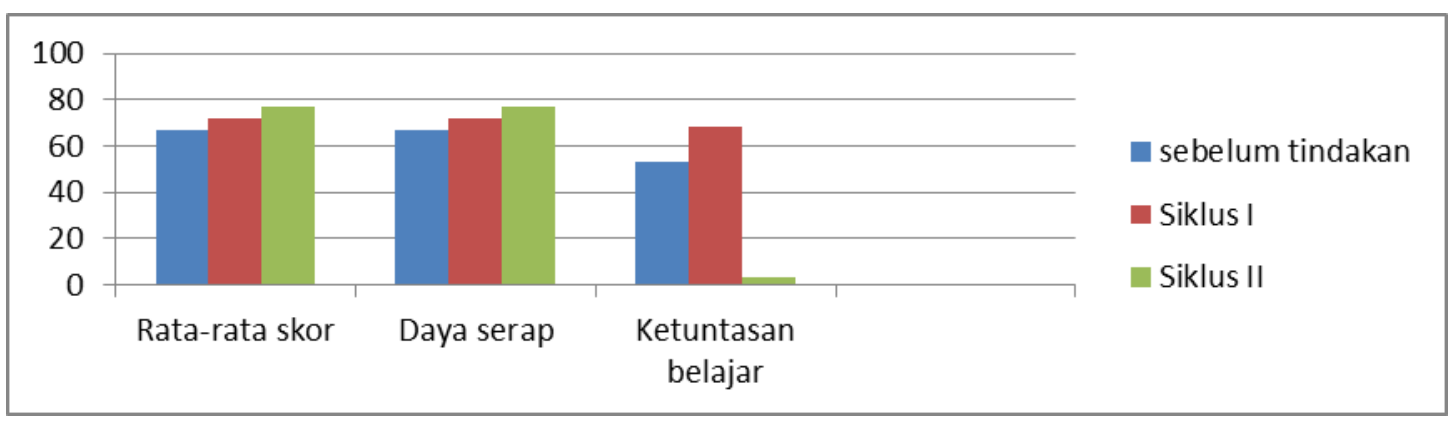

Gambar 1. Hasi Belajar Sebelum Tindakan, Siklus I, Siklus II

Berdasarkan tabel data di atas dapat dijelaskan bahwa rata-rata skor sebelum tindakan diperoleh 66,58 dengan ketuntasan belajar $52,63 \%$. Pada siklus I rata-rata skor diperoleh 71,71 dengan ketuntasan belajar $68,42 \%$, sedangkan pada siklus II rata-rata skor yang diperoleh 74,24 dengan ketuntasan belajar 97,37\%. Dari hasil penelitian siklus I sanpai dengan siklus II terjadi peningkatan yang signifikan. Namun dari 38 orang siswa masih ada satu orang yang belum mncapai ketuntasan belajar, dari hasil observasi dan wawancara dengan wali kelasnya bahwa anak bersangkutan termasuk anak inklusif termasuk anak yang lamban belajar. Tetapi ketuntasan minimal secara kelasikal telah berada di atas $75 \%$.

Hasil penelitian ini diperkuat dengan hasil penelitian yang dilakukan oleh Akhmad Suyono pada tahun 2013 yang berjudul Penerapan Model Pembelajaran Kooperatif Tipe STAD (Student Teams Achievement Division) Untuk Meningkatkan Hasil Belajar Siswa. Hasil penelitian menunjukkan bahwa penerapan model pembelajaran kooperatif tipe STAD (Student 
Teams Achievement Division) dapat meningkatkan hasil belajar siswa kelas X-1 di SMA YLPI P-Marpoyan Pekanbaru.

\section{Simpulan dan Saran}

Berdasarkan hasil analisis dan pembahasan, dapat disimpulkan bahwa: melaluipenerapan model Pembelajaran Kooperatif tipe STAD dapat meningkatkan prestasi belajar Bahasa Inggris siswa kelas XI. AP 1 SMK Negeri 1 Tegallalang tahun pelajaranb 2016/2017.

Adapun saran yang dapat disampaikan sehubungan dengan hasil penelitian tindakan ini adalah sebagai berikut. (1) Memanfaatkan metode pembelajaran kooperatif tipe STAD sebagai salah satu alternatif untuk meningkatkan hasil belajar siswa dalam proses belajar mengajar. Diharapkan kepada guru XI SMK Negeri 1 Tegallalang untuk tetap menerapkan model pembelajaran kooperatif tipe STAD sebagai alternatif meningkatkan hasil belajar siswa. (2) Kepada pembaca yang berminat mengadakan penelitian lebih lanjut mengenai model pembelajaran kooperatif tipe STAD pada mata pelajaran Bahasa Inggris maupun mata pelajaran lainnya, agar memperhatikan segala kendala - kendala yang peneliti alami sebagai bahan pertimbangan untuk perbaikan dan penyempurnaan pelaksanaan penelitian.

\section{Daftar Pustaka}

Agung, A.A Gede. 1999. Metodelogi Penelitian.Singaraja : STKIP Singaraja.

Arikunto, S. 2008. Prosedur Penelitian Suatu Pendekatan Praktik. Jakarta: Rineka Karya.

Djamrah, Syaiful Bahri. 2000. Guru Dan Anak Didik Dalam Interaksi Edukatif Jakarta : Rineke Cipta.

Hastut, Eka Fitri. 2017. Penerapan Model Pembelajaran Kooperatif Tipe STAD untuk Meningkatkan Kemampuan Berpendapat. Jurnal Pesona Vol. 3. No. 2 Hal. 133-143. Tersedia Pada: https://doi.org/10.26638/jp.443.2080.

Kadang, ST. Aminah, Jonner Nainggolan. 2017. Pengaruh Model Pembelajaran Kooperatif Tipe Student Teams Achievment Division (STAD) terhadap Keaktifan dan Hasil Belajar Fisika pada Materi Gelomang Siswa Kelas XII IPA SMA Negeri 2 Kabupaten Sorong. Jurnal IImu Pendidikan Indonesia Vol. 5 No. 1 Hal. 43-54. Tersedia Pada: https://ejournal.uncen.ac.id/index.php/JIPI/article/view/236/208.

Kemendikbud. 2013. Kerangka Dasar Kurikulum 2013. Jakarta: Kementerian Pendidikan dan Kebudayaan.

Killen, Roy. 1996. Effetive Teaching Strategies. Australia : Social Science Press.

Philip. Keller. 2006. Manajemen Pemasaran. Jilid Dua. Edisi. Kesepuluh. Alih Bahasa Benyamin Molan. Jakarta : Indeks.

Rusman. (2012). Model-model pembelajaran, mengembangkan profesionalitas guru. Jakarta: Rajawali Pers.

Rusman. 2014. Model-Model Pembelajaran. Jakarta: Raja Grafindo Persada.

Suyono, Akhmad. 2013. Penerapan Model Pembelajaran Kooperatif Tipe STAD (Student Teams Achievement Division) Untuk Meningkatkan Hasil Belajar Siswa. E-Jurnal UM Volume 1 Nomor 4.

Wardana, Ika, Tinggi Banggali, Halimah Husain. 2017. Penerapan Model Pembelajaran Kooperatif Tipe Student Team Achivement Division (STAD) untuk Meningkatkan Hasil Belajar Siswa Kelas XI IPA Avogadro SMA Negeri 2 Pangkajene (Studi pada Materi Asam Basa). Jurnal Chemica Vol. 18 No. 1 Hal. 76 - 84. Tersedia Pada: http://ojs.unm.ac.id/chemica/article/view/4678. 
JP2, Vol 2 No 3, Tahun 2019

p-ISSN : 2614-3909 e-ISSN : 2614-3895

Widyastuti, Tri Indah. 2012. Penerapan Model Pembelajaran Kooperatif Tipe Stad Berbasis Contextual Teaching And Learning (CTL) dalam Rangka Meningkatkan Prestasi Siswa untuk Mata Pelajaran IImu Pengetahuan Sosial Ekonomi. Jurnal Pendidikan Inssan Mandiri Vol. 1 No. 1 Hal. 1-15. Tersedia Pada: https://jurnal.uns.ac.id/jpim/article/view/16294/13230. 